Jurnal Ekonomi dan Perbankan Syariah

Vol. 7. No.2, Agustus, 2018: 27-44, ISSN (cet): 2355-1755 | ISSN (online): 2579-6437

\title{
EFEKTIVITAS PENDAYAGUNAAN DANA ZAKAT TERHADAP PENGEMBANGAN PROGRAM PEMBERDAYAAN EKONOMI MASYARAKAT PADA ZONA MADINA DOMPET DHUAFA
}

\author{
Rifqi Hattan ${ }^{1}$, Nining Nurhasanah' ${ }^{2}$ Firmansyah $^{3}$ \\ ${ }^{\text {I} P r o g r a m ~ S t u d i ~ P e r b a n k a n ~ S y a r i a h ~ S e k o l a h ~ T i n g g i ~ E k o n o m i ~ I s l a m ~ S E B I, ~ D e p o k, ~ J a w a ~ B a r a t . ~}$ \\ Email: rifqi.hattan@gmail.com, \\ ${ }^{2}$ Program Studi Perbankan Syariah Sekolah Tinggi Ekonomi Islam SEBI, Depok, Jawa Barat. \\ Email: nining2010@gmail.com, \\ ${ }^{3}$ Ketua Program Studi Perbankan Syariah Sekolah Tinggi Ekonomi Islam SEBI, Depok, Jawa \\ Barat. Email: firms134@gmail.com
}

\begin{abstract}
This research is to analyze the effectiveness of the utilization of zakat funds to the development of community economic empowerment program at Zona Madina Dompet Dhuafa. This research uses quantitative approach with explanatory and explorative research type. Data collection through field observation, interviews, and documentation studies. The data analysis used the calculation of effectiveness ratio and Wilcoxon Signed Rank Test to analyze the effect of the program on the condition of beneficiary community between before and after program. The results of this study show the utilization of zakat funds to the community economic empowerment program at Zona Madina Dompet Dhuafa from 2015-2017 amounted to 99.92\%. So that the utilization of zakat funds to the community economic empowerment program in Zona Madina Dompet Dhuafa has been very effective, because the effectiveness ratio shows $>90 \%$. Then based on statistical test nonparametrik Wilcoxon showed that the community economic empowerment program positively affect the changing economic conditions of the beneficiary community program.
\end{abstract}

Keywords: Effectiveness, Utilization, Zakat, Empowerment, Zona Madina Dompet Dhuafa

\section{PENDAHULUAN}

Di zaman yang sudah modern ini, kemiskinan masih menjadi permasalahan yang cukup serius di negara ini. Data terbaru Badan Pusat Statistik (BPS) menyebutkan bahwa jumlah persentase penduduk miskin pada Maret 2017 diangka 10,64 persen. Hal ini menunjukan bahwa ada peningkatan dalam mengatasi kemiskinan jika dibandingkan dengan Bulan Maret 2016 yaitu 10,86. Walaupun angka ini turun 0,22 persen dari tahun lalu, namun angka kemiskinan dipastikan akan jauh membesar secara signifikan jika pengukuran dilakukan dengan standar batas kemiskinan global yang dikeluarkan oleh Bank Dunia, yang setara dengan USD 1,9 per kapita per hari.

Menurut Mintarti (2011: kata pengantar) pengentasan kemiskinan memerlukan strategi, konsep matang serta ukuran program yang jelas. Kita perlu ketegasan parametikal menyangkut seberapa miskinkah, atau miskin tidaknya seseorang di tengah sebuah masyarakat. Hal ini perlu untuk mendapatkan gambaran jelas pola dan penetapan sasaran pengetasan kemiskinan di sebuah tempat, masyarakat atau suatu negeri. Ia menambahkan bahwa Islam, menetapkan parameter standar kemiskinan yang relatif 

Madina Dompet Dhuafa

komprehensif, yakni yang disebut had al kifayah - sebagai Islamic Poverty Line. Dalam paradigma Islam, setidaknya ada lima dimensi parameter yang harus dilindungi untuk menjamin kesejahteraan manusia, yaitu: agama, kekayaan, akal, keturunan dan diri/jiwa. Parameter ini sangat kontras jika dibandingkan dengan standar kemiskinan yang dipakai pemerintah saat ini yang hanya melihat garis kemiskinan dari sisi pendapatan dan pengeluaran berdasarkan standar makanan dan bukan makanan. Selain itu had al kifayah menghitung berapa tingkat kebutuhan yang diperlukan rumah tangga dalam memenuhi kebutuhan hidupnya, sedangkan garis kemiskinan hanya berbicara pada aspek pendapatan minimal yang diperlukan. Bersebab inilah, maka masuk akal jika had al kifayah diyakini lebih bersifat komprehensif, holistik dan lebih baik dibanding pendekatan garis kemiskinan yang ada.

Menurut Nafik dalam (Mintarti, 2011:187) islam melarang umatnya menimbun harta dan atau membiarkannya tidak produktif. Dalam prespektif Islam, harta harus senantiasa berputar agar memberikan kemaslahatan lebih bagi pemiliknya sendiri, bagi orang lain maupun lingkungannya. Dengan demikian harta tersebut tidak hanya berputar diantara orang-orang kaya saja.

Indonesia merupakan salah satu negara dengan mayoritas penduduk Muslim yaitu sejumlah 216,66 juta penduduk atau dengan persentase Muslim sebesar 85 persen dari total populasi (BPS, 2015). Fakta ini menyiratkan bahwa zakat memiliki potensi besar dan dapat berkontribusi dalam mengurangi kemiskinan (Badan Amil Zakat Nasional, 2016:11). Menurut Nafik dalam (Mintarti, 2011:180) memaparkan bahwa zakat, infak, sedekah, dan wakaf (ZISWAF) merupakan sistem intrumen ekonomi dalam islam untuk mempererat hubungan antara manusia. Zakat merupakan kewajiban bagi mereka yang mendapatkan keuntungan yang mencapai nisab, dengan nilai yang telah ditentukan, dan harus memenuhi ketentuan lainnya. Infak merupakan kewajiban sebagai wujud kepedulian terhadap mereka yang membutuhkan, tetapi besarnya bersifat sukarela sesuai dengan kemampuan. Sementara sedekah merupakan kewajiban sebagai wujud empati terhadap orang lain baik yang membutuhkan maupun yang tidak membutuhkannya. Dengan demikian, ZISWAF dapat digunakan sebagai instrumen untuk meningkatkan perkembangan, pertumbuhan dan pemberdayaan masyarakat baik secara mikro ekonomi maupun makro ekonomi.

Menurut Ryandono (2008:55) dalam (Mintarti, 2011:238) menjelaskan bahwa zakat memiliki kemampuan mendorong perekonomian baik dalam jangka pendek maupun jangka panjang, tergantung dari bagaimana pengelolaannya. Apabila pengelolaannya hanya memungut zakat kemudian membagikannya kepada yang berhak menerimanya (mustahik), maka hal ini hanya akan memberikan daya dorong dalam jangka pendek atau bersifat sementara. Akan tetapi, apabila zakat digunakan untuk memberdayakan ekonomi mustahik maka ia akan mampu memberikan daya dorong dalam jangka panjang. Dalam penyerahan zakat, hendaknya melalui badan/lembaga pengelola zakat agar didayagunakan secara efektif. Menurut Qadir (1998) dalam (Hafidhuddin, 2002:126) mengatakan bahwa pengelolaan zakat oleh lembaga pengelola zakat, apalagi yang memiliki kekuatan hukum formal, akan 
Jurnal Ekonomi dan Perbankan Syariah

Vol. 7. No.2, Agustus 2018: 27-44, ISSN (cet): 2355-1755 | ISSN (online): 2579-

6437

| 29

memiliki beberapa keuntungan, antara lain : pertama, untuk menjamin kepastian dan disiplin pembayar zakat. Kedua, untuk menjaga perasaan rendah diri para mustahik zakat apabila berhadapan langsung untuk menerima zakat dari para muzakki. Ketiga, untuk mencapai efesien dan efektivitas, serta sasaran yang tepat dalam penggunaan harta zakat menurut skala prioritas yang ada pada suatu tempat. Keempat, untuk memperlihatkan syiar Islam dalam semangat penyelenggaraan pemerintahan yang islami. Sebaliknya, jika zakat diserahkan langsung dari muzakki kepada mustahik, meskipun secara hukum syariah adalah sah, akan tetapi di samping akan terabaikannya hal-hal tersebut diatas, juga hikmah dan fungsi zakat, terutama yang berkaitan dengan kesejahteraan umat, akan sulit diwujudkan.

Menurut Ibrahim (2006) dalam (Mintarti, 2011:49) memaparkan bahwa lembaga-lembaga zakat memiliki misi untuk memastikan dan meyakinkan masyarakat awam bahwa tidak hanya dana zakat yang terkumpul akan disalurkan sesuai dengan prinsip syariah, tapi juga bahwa dana tersebut akan ditangani secara profesional dan efesien.

Imam Qurtubi dalam (Hafidhuddin, 2002:233) menyatakan bahwa amil zakat adalah orang-orang yang ditugaskan (oleh Imam/pemerintah) untuk mengambil, menuliskan, menghitung dan mencatatkan zakat yang sedang diambilnya dari para muzaki untuk kemudian diberikan kepada yang berhak menerimanya. Peran amil tersebut saat ini dijalankan oleh Badan Amil Zakat atau Lembaga Amil Zakat.

Sudarsono dalam (Mintarti, 2011:234) menyebutkan undang-undang nomor 3 tahun 1999 tentang pengelolaan zakat di Indonesia terdiri atas dua kelompok institusi, yaitu (BAZ) Badan Amil Zakat dan (LAZ) Lembaga Amil Zakat. BAZ dibentuk oleh pemerintah, sedangkan LAZ dibentuk oleh masyarakat. Dalam buku (Badan Amil Zakat Nasional, 2016:3) menyatakan bahwa perubahan besar pada kerangka regulasi mengenai zakat di Indonesia terjadi saat digantinya UU No. 38/1999 ini dengan UU No. 23/2011 mengenai Pengelolaan Zakat. Salah satu hal yang cukup penting dalam UU ini adalah adanya aturan mengenai wewenang Badan Amil Zakat Nasional (BAZNAS) sebagai koordinator pengelolaan zakat nasional. Salah satu lembaga zakat yang sudah lama berdiri di Indonesia ialah Dompet Dhuafa. Dompet Dhuafa (DD) merupakan sebuah yayasan yang didirikan untuk menyalurkan dana umat demi kepentingan masyarakat Indonesia terutama masyarakat yang lemah. Selaras dengan pengertian yayasan oleh Kasmir (2012) bahwa yayasan merupakan badan usaha yang tidak bertujuan mencari keuntungan, tetapi lebih menekankan usahanya pada tujuan sosial. Modal yayasan diperoleh dari sumbangan, wakaf, hibah dan sumbangan lainnya. Yayasan memiliki dewan pengurus yang mengurusi kegiatan yayasan. Pendirian yayasan didirikan untuk bidang pendidikan, kesehatan, panti sosial atau lembaga swadaya masyarakat.

DD memiliki kawasan pemberdayaan dan pengembangan dengan konsep masyarakat Islam. Konsep yang dibangun DD berdasarkan ajaran Islam yang rahmatan lil alamin. Kawasan tersebut bernama Zona Madina (ZM) 

Madina Dompet Dhuafa

yang terletak di Desa Jampang, Kecamatan Kemang, Kabupaten Bogor. Zona Madina Dompet Dhuafa adalah kawasan pemberdayaan umat terpadu yang dibangun diatas tanah seluas 3,6 hektar (Company Profile Zona Madina Dompet Dhuafa). Kawasan yang berada di jalan Parung KM 42 ini, di bangun berbasis nilai ke-Islaman yang kokoh, ZM dirancang untuk pemberdayaan komunitas. Di area tersebut terdapat Rumah Sehat Terpadu (RST), sekolah unggulan SMART Ekselensia Indonesia, kompleks rumah susun sederhana, area pusat inkubasi bisnis UKM, perpustakaan digital, gedung pelatihan, area outbound, masjid, sarana olahraga, gedung pertemuan, pusat perkantoran dan pemberdayaan.

Zona Madina Dompet Dhuafa dalam membangun masyarakat yang lebih berdaya, tidak fokus pada keuntungan pribadi. Ini terlihat pada visi dan misinya untuk pemberdayaan masyarakat. Pendanaanya pun bersumber dari dana sosial masyarakat dan donasi perusahaan dalam bentuk Ziswaf (zakat, infak, sedekah dan wakaf) serta dana lainnya yang halal dan legal dari perorangan, kelompok, perusahaan atau lembaga. Melalui program ComDev (Community Development), ZM berusaha mensinergikan tujuan sosial dengan kebutuhan masyarakat. Salah satu program ComDev yaitu program pemberdayaan ekonomi masyarakat. Menurut Dunham (1960) dalam (Mintarti, 2011:80) memberikan rumusan pemberdayaan masyarakat dengan penekanan bahwa pembangunan masyarakat merupakan usaha-usaha yang terorganisasi yang bertujuan untuk memperbaiki kondisi kehidupan masyarakat, dan memperdayakan masyarakat untuk mampu bersatu dan mengarahkan diri sendiri. Dalam hal ini program pemberdayaan ekonomi masyarakat Zona Madina Dompet Dhuafa yaitu dengan cara memberikan dana zakat kepada masyarakat yang membutuhkan. Lalu mereka akan menjadi mitra untuk membangun usaha agar kehidupan ekonominya terus berjalan dengan baik. Namun menurut (Mintarti, 2011:79) bahwa program pemberdayaan masyarakat berbasis zakat yang banyak diluncurkan oleh lembaga zakat, masih dirasakan belum optimal mencapai sasaran yang diharapkan, yakni kemandirian masyarakat secara ekonomis maupun sosial. Hal ini tidak terlepas dari kelemahan dalam desain program pemberdayaan itu, antara lain bahwa pemberdayaan sering dipersepsikan dan diterjemahkan secara sempit sebagai pemberian akses finansial berupa penyediaan dana bantuan kepada kelompok fakir miskin.

Pengukuran secara akurat atas dana zakat untuk pemberdayaan ekonomi masyarakat perlu dilakukan untuk mengetahui tingkat efektivitas pencapaian keberhasilan pendayagunaan zakat. Mengukur secara akurat ini penting sebab Zona Madina Dompet Dhuafa tidak dapat membantu mustahik secara efektif jika tidak mengetahui pengetahuan dan ketrampilan yang dikuasai setiap mustahiknya dan kekurangan apa yang masih menjadi masalah bagi mustahik. Adapun indikator untuk mengukur efektivitas suatu program dapat dilakukan dengan cara menggunakan variabel ketetapan sasaran program, sosialisasi program, tujuan program, dan pemantauan program. Dan pengetahuan tentang indikasi efektivitas dalam memberikan zakat terhadap 
Jurnal Ekonomi dan Perbankan Syariah

Vol. 7. No.2, Agustus 2018: 27-44, ISSN (cet): 2355-1755 | ISSN (online): 2579-

6437

| 31

pemberdayaan ekonomi mustahik juga sama pentingnya sebagai masukan untuk perbaikan program pendayagunaan zakat.

Berdasarkan uraian di atas, penulis tertarik untuk mengadakan penelitian dengan judul : "Efektivitas Pendayagunaan Dana Zakat terhadap Pengembangan Program Pemberdayaan Ekonomi Masyarakat pada Zona Madina Dompet Dhuafa."

\section{LANDASAN TEORI}

\subsection{Pengertian Efektivitas}

Istilah efektivitas merupakan kata yang sering muncul dalam mempelajari disiplin ilmu administrasi negara. Bagi sebagian orang yang belum memahaminya sering menyamakan istilah efektivitas dengan efisiensi. Efektivitas sendiri didefinisikan oleh para pakar dengan kalimat yang berbedabeda tergantung pendekatan yang digunakan oleh masing-masing pakar (Wahyu, 2011:17).

Menurut Pasolong (2012:51) efektivitas pada dasarnya berasal dari kata "efek" dan digunakan dalam istilah ini sebagai hubungan sebab akibat. Efektivitas dapat dipandang sebagai suatu sebab dari variabel lain. Efektivitas berarti bahwa tujuan yang telah direncanakan sebelumnya dapat tercapai atau dengan kata sasaran tercapai karena adanya proses kegiatan.

Menurut Mardiasmo (2004:134) mengatakan bahwa efektivitas adalah ukuran berhasil tidaknya suatu organisasi mencapai tujuannya. Apabila suatu organisasi berhasil mencapai tujuan, maka organisasi tersebut dikatakan telah berjalan dengan efektif.

Menurut Bisma (2010: 78) tentang tujuan pengukuran efektivitas yaitu pengukuran tingkat efektivitas ini untuk mengetahui berhasil tidaknya pencapaian tujuan anggaran yang memerlukan data-data realisasi pendapatan dan target pendapatan. Pada penelitian ini penulis akan menjabarkan target dan realisasi anggaran yang ada.

\subsection{Pengertian Zakat}

Ditinjau dari segi bahasa, kata zakat mempunyai beberapa arti, yaitu $\mathrm{Al}$ barakatu 'keberkahan', Al-namnaa 'pertumbuhan dan perkembangan', Atthaharatu 'kesucian', dan Ash-shalahu 'keberesan'. Sedangkan secara istilah meskipun para ulama memiliki redaksi yang berbeda antara satu dengan yang lainnya, akan tetapi pada hakikatnya memiliki prinsip yang sama, yaitu bahwa zakat itu adalah bagian harta yang dengan persyaratan tertentu, yang Allah SWT mewajibkan kepada pemiliknya untuk diserahkan kepada yang berhak menerimanya, dengan persyaratan tertentu pula. (Hafidhuddin, 2002:17)

Menurut Qaradhawi (2009:77), urgensi zakat dalam Islam sangat berkaitan dengan dua dimensi sekaligus, yaitu ubudiyah (ketuhanan) dan ijtima'iyyah waiqtishadiyyahi (ekonomi kemasyarakatan). Qaradhawi (2009:79) menambahkan bahwa zakat dapat berfungsi sebagai pembeda antara 

Madina Dompet Dhuafa

keislaman dan kekafiran, antara keimanan dan kemunafikan, serta antara ketaqwaan dan kedurhakaan.

Jadi dapat disimpulkan bahwa zakat adalah kewajiban setiap muslim sesuai syarat dan ketentuan yang telah ditentukan berdasarkan nishab dan khaulnya. Zakat tidak akan menjadikan orang yang memberikannya menjadi miskin melainkan harta yang ia miliki akan menjadi bersih, tumbuh dan bermanfaat.

\subsection{Efektivitas Pendayagunaan Dana Zakat}

Menurut (Mintarti, 2011:77) tujuan pendayagunaan zakat adalah mengangkat kelompok fakir miskin keluar dari kemiskinan, memperbaiki kualitas hidup serta melakukan proses transformasi dari mustahik menjadi muzaki. Upaya untuk melakukan proses transformasi dari mustahik menjadi muzaki tidak akan terwujud apabila proses pemberdayaan masyarakat, yang diawali dengan mengubah cara pandang masyarakat dari pasrah, pasif dan ketergantungan menjadi aktif-partisipatif.

Mintarti menambahkan bahwa pemberdayaan masyarakat berbasis zakat adalah proses membangun kemajuan sosial dan ekonomi bagi kelompok fakir miskin melalui partisipasi aktif kelompok fakir miskin itu sendiri dengan difasilitasi oleh amil zakat yang berperan sebagai pendamping program. Kelompok fakir miskin dipandang sebagai anggota masyarakat yang juga memiliki potensial, hanya saja potensial tersebut belum sepenuhnya dikembangkan. Amil zakat membantu meningkatkan kesadaran dan kemampuan kelompok fakir miskin dalam mencapai tujuan-tujuan yang diharapkan.

\subsection{Pemberdayaan Ekonomi Masyarakat}

Pemberdayaan menurut bahasa berasal dari kata daya yang berarti tenaga/kekuatan. Pemberdayaan adalah upaya yang membangun daya masyarakat dengan mendorong, memotivasi dan membangkitkan kesadaran akan potensi yang dimiliki serta berupaya untuk mengembangkannya (Mubyarto, 2000: 263).

Menurut Gunawan (1999:66) Pemberdayaan diarahkan guna meningkatkan ekonomi masyarakat secara produktif sehingga mampu menghasilkan nilai tambah yang tinggi dan pendapatan yang lebih besar. Upaya peningkatan kemampuan untuk menghasilkan nilai tambah paling tidak harus ada perbaikan akses terhadap empat hal, yaitu akses terhadap sumber daya, akses terhadap teknologi, akses terhadap pasar dan akses terhadap permintaan.

Menurut (Mintarti, 2011:236) bahwa salah satu indikator bahwa masyarakat miskin telah mengalami pemberdayaan ekonomi adalah dengan meningkatnya kemampuan dan daya beli (konsumsi) masyarakat untuk memenuhi kebutuhan-kebutuhan hidup yang meliputi makanan, pakaian, rumah, pendidikan, kesehatan dan rekreasi. 
Jurnal Ekonomi dan Perbankan Syariah

Vol. 7. No.2, Agustus 2018: 27-44, ISSN (cet): 2355-1755 | ISSN (online): 2579-

6437

\section{| 33}

\section{METODOLOGI PENELITIAN}

Menurut pendekatannya, penelitian ini termasuk penelitian kuantitatif yaitu suatu pendekatan penelitian yang bersifat objektif, mencakup pengumpulan dan analisis data kuantitatif serta menggunakan metode pengujian statistik (Hermawan, 2003:3). Penelitian ini termasuk pada penelitian eksplanasi, yaitu menjelaskan tentang mengapa suatu kejadian atau gejala terjadi dengan menghubungkan pola-pola yang berbeda namun memiliki keterkaitan. Dari sisi metodenya, penelitian ini termasuk penelitian studi kasus yaitu penelitian dengan karakteristik masalah yang berkaitan dengan latar belakang dan kondisi saat ini dari subjek yang diteliti, serta interaksinya dengan lingkungan. Subjek yang diteliti berupa individu, kelompok, lembaga atau komunitas tertentu. (Rochaety dkk, 2007:16).

Untuk menganalisis efektivitas, data yang terkumpul akan dianalisis melalui pendekatan kuantitatif. Pengujian melalui analisis kuantitatif digunakan untuk mengukur dampak efektivitas pendayagunaan dana zakat terhadap pengembangan program secara ekonomi terhadap 2 (dua) aspek, yaitu rasio efektivitas dan perubahan kondisi ekonomi.

\section{Rasio Efektivitas}

Efektivitas program $=\mathrm{R} / \mathrm{T}$ X $100 \%($ Subagyo $: 2000)$

Keterangan :

$\mathrm{R}=$ Realisasi dana zakat profesi yang dihimpun dan disalurkan.

$\mathrm{T}=$ Target dana zakat profesi yang dihimpun dan disalurkan.

Table 3.1 Kriteria Efektivitas Pendayagunaan Dana Zakat pada Zona Madina Dompet Dhuafa

\begin{tabular}{|l|l|}
\hline Kriteria & Penilaian \\
\hline Sangat Efektif & $>90 \%$ \\
\hline Baik & $80-90 \%$ \\
\hline Cukup & $60-79 \%$ \\
\hline Kurang & $40-59 \%$ \\
\hline Sangat Kurang & $\mathbf{2 0 - 3 9 \%}$ \\
\hline
\end{tabular}

Sumber : Pedoman Pengawasan Lembaga Pengelola Zakat Kementerian Agama RI tahun 2012, Jakarta.

Kriteria efektivitas bernilai 20-39\%, maka penghimpunan dan penyaluran dana zakat profesi sangat kurang efektif. Kriteria efektivitas bernilai 40-59\% dinyatakan kurang efektif, kriteria efektivitas bernilai $60-79 \%$ dinyatakan cukup efektif, kriteria efektivitas bernilai $80-90 \%$ dinyatakan efektif, dan jika kriteria efektivitas bernilai $>90 \%$, maka penghimpunan dan penyaluran dana zakat dinyatakan sangat effektif.

\section{Perubahan Kondisi Ekonomi}



Madina Dompet Dhuafa

Pengukuran terhadap perubahan kondisi ekonomi karyawan/peternak binaan dan hubungannya terhadap pelaksanaan program menggunakan tes statistik nonparametrik Wilcoxon Signed Rank Test (uji dua sampel berhubungan) dengan rumus sebagai berikut:

Keterangan:

$$
\begin{gathered}
E(T)=\frac{n(n+1)}{4} \times 100 \% \\
\sigma T=\frac{\sqrt{n(n+1)(2 n+1)}}{24} \times 100 \%
\end{gathered}
$$

$$
\begin{aligned}
& \mathrm{E}=\text { Mean (rataan hitung) } \\
& \sigma=\text { Simpangan baku } \\
& \mathrm{T}=\text { Jumlah jenjang/ranking } \\
& \mathrm{N}=\text { Jumlah sampel }
\end{aligned}
$$

Untuk landasan pengujian dipergunakan nilai T. H0 diterima apabila T $\geq \mathrm{T} \alpha$. H0 ditolak apabila $\mathrm{T}<\mathrm{T} \alpha$ (Djarwanto, 2003:26).

Metode statistik nonparametrik digunakan karena nilai data variabel tergolong kepada data nonmetrik. Data nonmetrik adalah data kualitatif yang dapat berbentuk suatu atribut, karakteristik atau kategori atau dikotomi. Yang termasuk data nonmetrik adalah tipe data nominal atau ordinal.

Data mengenai kondisi ekonomi dimaksud ialah kondisi pendapatan masyarakat penerima bantuan yang dimiliki. Kondisi ekonomi responden dibandingkan antara sebelum dan sesudah diberikan program, apakah terjadi peningkatan atau-kah penurunan. (Jogiyanto HM, 2004:65)

Pengolahan data secara kuantitatif dilakukan dengan mengunakan program SPSS, untuk efektivitas dan efisiensi serta menghindari human error. Objek dalam penelitian ini adalah Zona Madina Jl. Raya Parung - Bogor km. 42 Ds. Jampang Kec. Kemang Kab. Bogor 16310.

Penelitian ini menggunakan data primer dan data sekunder. Data primer adalah Data primer merupakan data-data yang peneliti peroleh dari lapangan (field research). Sedangkan data sekunder penulis melakukan study kepustakaan (library research) yaitu dengan mempelajari buku kepustakaan, literatur, majalah serta materi kuliah yang berkaitan erat dengan pembahasan ini.

Teknik pengumpulan data yang digunakan :

1. Observasi yaitu mengamati dan melihat lebih dekat mengenai efektivitas pendayagunaan dana zakat yang disalurkan oleh Zona Madina Dompet Dhuafa terhadap pengembangan program pemberdayaan ekonomi masyarakat.

2. Wawancara yaitu menurut Arikunto (1998:232) wawancara merupakan metode pengumpulan data dengan cara melakukan tanya jawab secara lisan kepada pihak yang akan diteliti.

3. Studi Dokumentasi yaitu pengumpulan data-data yang diperlukan dengan cara mencari data dokumentasi tentang efektivitas pendayagunaan dana zakat yang disalurkan Zona Madina Dompet 
Jurnal Ekonomi dan Perbankan Syariah

Vol. 7. No.2, Agustus 2018: 27-44, ISSN (cet): 2355-1755 | ISSN (online): 25796437

\section{| 35}

Dhuafa terhadap pengembangan program pemberdayaan ekonomi masyarakat.

\section{PEMBAHASAN}

\subsection{Gambaran Umum Zona Madina Dompet Dhuafa}

Zona Madina Dompet Dhuafa adalah kawasan pemberdayaan umat terpadu yang dibangun di atas tanah seluas 3,6 Hektar di wilayah Parung Bogor. Zona Madina didesain dan dikembangkan dengan konsep kawasan tumbuh dan terpadu dengan landasan tata nilai Islam yang rahmatan lil alamin dengan tujuan sebesar-besarnya membangun pemberdayaan dalam arti luas meliputi pembangunan sosioekonomi, budaya dan pengembangan nilai religi dengan masjid sebagai pusat sentra kawasan. Desain program Zona Madina selalu memperhatikan nilai-nilai lokal yang dikembang masyarakat Indonesia, serta donasi perusahaan, pemerintah serta upaya-upaya lain yang halal. Zona Madina dimulai pembangunannya pada 7 Januari 2009 bertepatan dengan 10 Muharam 1030 H dimulai dengan pembangunan Rumah Sakit Zakat terbesar di Indonesia yaitu Rumah Sehat Terpadu Dompet Dhuafa.

Hasil wawancara dengan direktur Zona Madina tentang visi Zona Madina Dompet Dhuafa adalah terwujudnya kawasan Zona Madina yang terpadu, berdaya dan mendunia melalui pengelolaan ZISWAF pada tahun 2022.

Misi Zona Madina Dompet Dhuafa yaitu mengoptimalkan peran Zona Madina sebagai koordinator kawasan terpadu, mewujudkan masyarakat berdaya melalui program yang terintegrasi, menjadikan model kawasan pengelolaan ZISWAF internasional dan mewujudkan kampung silat Jampang yang mendunia.

Bagan 4.1 Struktur Organisasi Zona Madina Dompet Dhuafa 
36 | Rifqi Hattan, Nining Nurhasanah, Firmansyah : Efektivitas Pendayagunaan Dana Zakat Terhadap Pengembangan Program Pemberdayaagunaan Ekonomi Masyarakat Pada Zona Madina Dompet Dhuafa

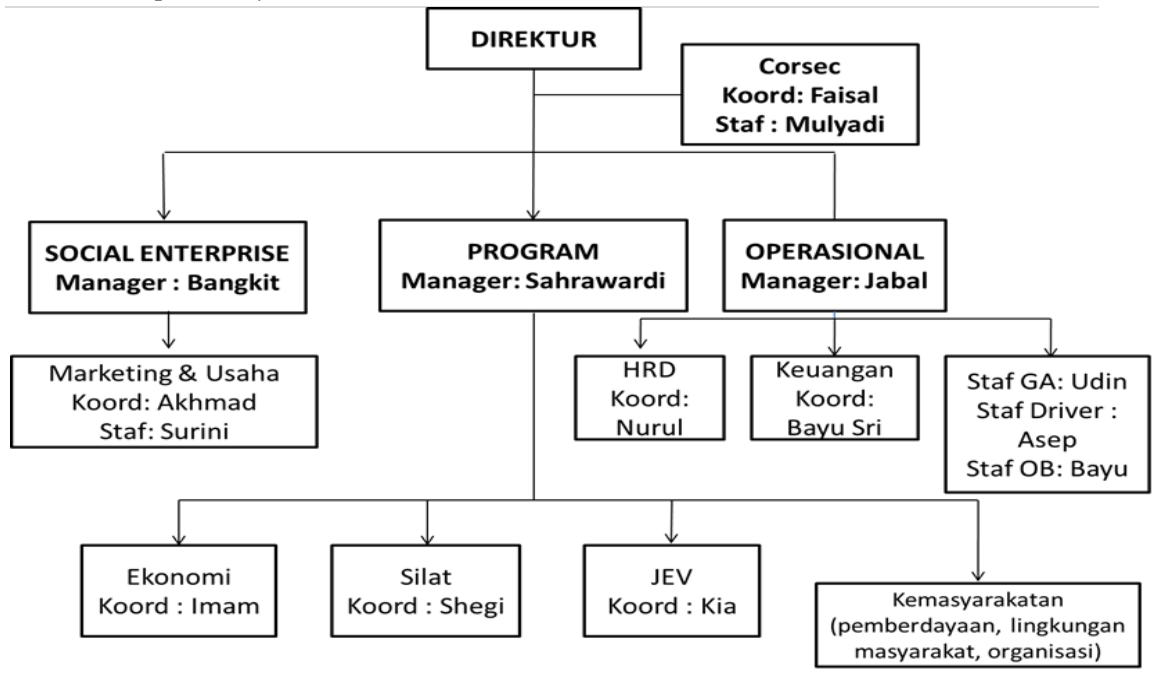

Sumber : hasil wawancara dengan direktur Zona Madina Pak Herman Budianto

\subsection{Hasil Temuan Penelitian}

Dalam praktiknya Zona Madina bertanggung jawab terhadap 4 kecamatan dan 17 desa dan mereka tidak memberikan dana zakat secara konsumtif melainkan secara produktif. Jadi masyarakat yang sudah menerima bantaun usaha dari program pemberdayaan ekonomi masyarakat tidak ada yang mendapatkan zakat secara konsumtif kecuali masyarakat tersebut mendapatkan bantuan dari lembaga atau pihak lain.

Berikut data target cakupan desa di setiap kecamatan :

Grafik 4.1 Target Cakupan Desa di 4 Kecamatan

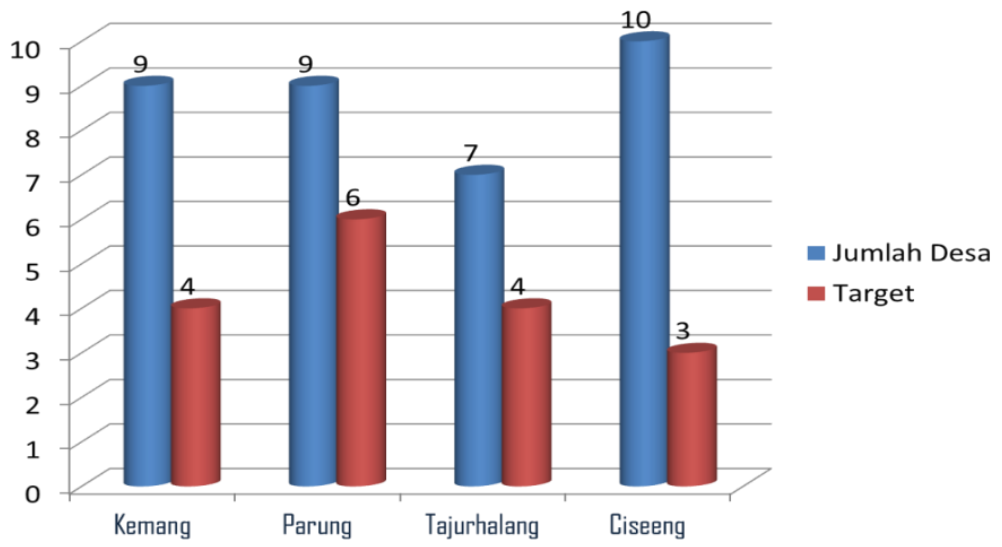

Sumber : Laporan Ekografis Sebaran Penerima Manfaat Zona Madina 2016 
Jurnal Ekonomi dan Perbankan Syariah

Vol. 7. No.2, Agustus 2018: 27-44, ISSN (cet): 2355-1755 | ISSN (online): 25796437

| 37

Berdasarkan data grafik di atas 4 Kecamatan yang menjadi tanggung jawab program pemberdayaan ekonomi masyarakat yaitu Kecamatan Kemang, Parung, Tajurhalang dan Ciseeng. Zona Madina menargetkan 4 Desa dari 9 Desa yang ada di Kecamatan Kemang, 6 Desa dari 9 Desa yang ada di Kecamatan Parung, 4 Desa dari 7 Desa yang ada di Kecamatan Tajurhalang dan 3 Desa dari 10 Desa yang ada di Kecamatan Ciseeng. Tujuan Zona Madina membuat program pemberdayaan ekonomi masyarakat ialah menjadikan dan membantu masyarakat dalam meningkatkan pendapatan untuk mencukupi kebutuhan sehari-hari melalui berwirausaha.

Berikut jumlah masyarakat penerima manfaat program pemberdayaan ekonomi masyarakat :

Grafik 4.2 Jumlah Masyarakat Penerima Manfaat

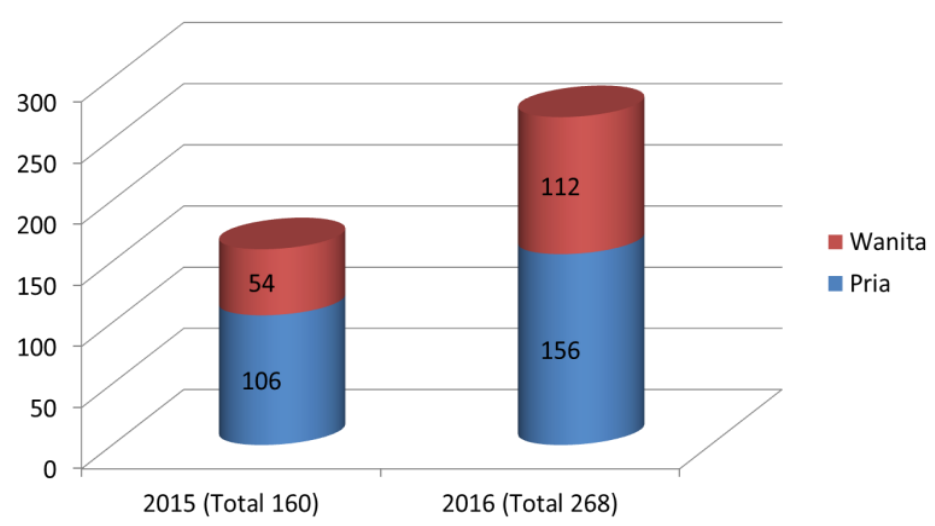

Sumber : Laporan Ekografis Pemberdayaan Program Zona Madina 2016

Berdasarkan data grafik di atas, masyarakat penerima manfaat bantuan program pemberdayaan ekonomi pada tahun 2015 berjumlah 160 orang dan pada tahun 2016 berjumlah 268 orang. Ada jumlah peningkatan penerima manfaat dari tahun 2015 ke tahun 2016. Hal ini mengungkapkan bertambahnya masyarakat yang terbantu untuk meningkatkan pendapatan mereka sehari-hari. Akad perjanjian yang dilakukan dalam bantuan program ini yaitu qardul hasan (pinjaman kebajikan, yakni kredit tanpa bunga) ditahun pertama, dengan pengembalian $10 \%$ dari modal awal setiap bulannya. Hal ini dilakukan untuk 
38 | Rifqi Hattan, Nining Nurhasanah, Firmansyah : Efektivitas Pendayagunaan Dana Zakat Terhadap Pengembangan Program Pemberdayaagunaan Ekonomi Masyarakat Pada Zona Madina Dompet Dhuafa

memastikan usaha yang dijalankan berjalan dengan baik dan ada rasa tanggung jawab. Setelah itu, di tahun kedua akad yang dijalankan bisa menjadi hibah.

Program pemberdayaan ekonomi masyarakat ini dibagi menjadi beberapa jenis usaha. Berikut data jenis usaha para penerima bantuan program:

Grafik 4.3 Grafik Jenis Usaha Masyarakat Penerima Bantuan Program Pemberdayaan Ekonomi Masyarakat
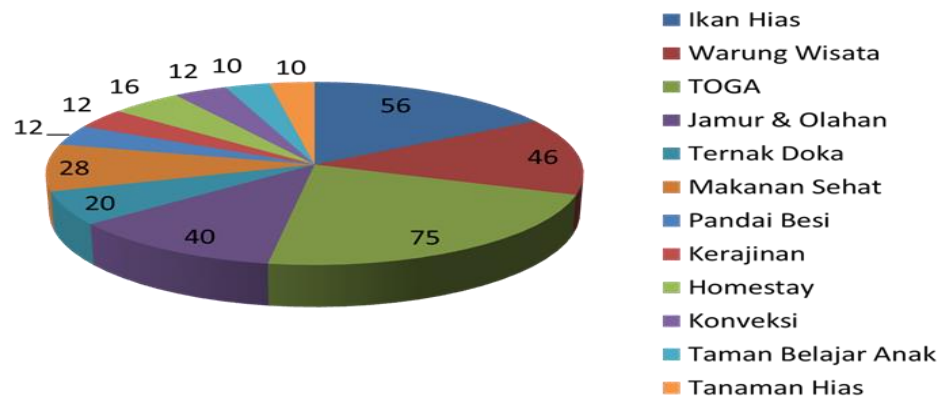

Sumber : Laporan Ekografis Sebaran Penerima Manfaat Zona Madina 2016

Berdasarkan grafik di atas jenis usaha para penerima manfaat sangat beragam, ada ikan hias, warung wisata, TOGA (bibit/siap panen), jamur dan olahan, ternak domba kambing, makanan sehat, pandai besi, kerajinan, homestay, konveksi, taman belajar anak dan tanaman hias.

Dalam menjalankan program ini agar berjalan dengan baik, Zona Madina melakukan cara pendampingan guna memberikan arahan kepada masyarakat penerima manfaat. Namun demikian berdasarkan hasil wawancara dan observasi ditemukan beberapa kendala baik dari pegawai Zona Madina penanggung jawab program pemberdayaan dan masyarakat penerima manfaat program ini.

a) Kendala yang dihadapi penanggung jawab program.

Dalam menjalankan program ini ditemukan beberapa kendala atau permasalahan yang biasa dihadapi yaitu :

1. Mental pengusaha yang masih belum percaya diri, kejujuran dalam komunikasi dan semangat dalam berwirausaha. Dalam mengatasinya pendamping membuat kelompok komunitas Zona Madina UKM Berdaya agar dalam komunitas itu dapat berdiskusi dan membantu sesama mitra.

2. Kondisi alam/cuaca dan lingkungan. Ada beberapa masyarakat mitra usaha yang belum bisa mengatasi permasalahan yang dihadapkan dengan cuaca yang kurang mendukung. Untuk membantu mengatasinya pendamping mengikutkan masyarakat mitra usaha pelatihan, guna menambah wawasan dalam hal terkait.

3. Mengantisipasi usaha yang mengalami kerugian. Apabila mitra usaha mengalami kesulitan dalam melakukan usaha hingga mengalami 
Jurnal Ekonomi dan Perbankan Syariah

Vol. 7. No.2, Agustus 2018: 27-44, ISSN (cet): 2355-1755 | ISSN (online): 2579-

6437

39

kerugian yang dilakukan Zona Madina yaitu dengan cara membantu mengarahkan dan menganalisa usahanya seperti catatan keuangannya sudah benar atau belum, pemasaran produk sudah lancar atau belum dan kelengkapan alat produksi yang dimiliki. Lalu apabila ada masyarakat mitra usaha yang mengalami kerugian dan tidak bisa mengembalikan $10 \%$ qardul hasan, maka akad bisa diganti bulan depannya menjadi hibah dengan alasan yang logis. Sehingga sampai saat ini belum ada mitra usaha yang gulung tikar.

b) Kendala yang dihadapi masyarakat.

Dalam menjalankan usahanya kendala yang dihadapi masyarakat ialah :

1. Faktor alam/cuaca yang mempengaruhi pertumbuhan di bidang budidaya jamur, ikan dan sejenisnya.

2. Pemasaran produk. Dalam hal ini Zona Madina membantu memasarkan produk-produk masyarakat melalui kantin Zona Madina, tamu kunjungan, acara seminar dan event/bazar.

Salah satu tujuan adanya program pemberdayaan ekonomi masyarakat ialah untuk membuka lapangan pekerjaan dengan berwirausaha dan meningkatkan pendapatan masyarakat.

Pada penelitian ini penulis mendapatkan data pendapatan masyarakat setiap bulannya sebelum mengikuti dan sesudah mengikuti program pemberdayaan ekonomi masyarakat pada Zona Madina.

Tabel 4. 1 Data Pendapatan Masyarakat Sebelum dan Sesudah Mengikuti Program

\begin{tabular}{|c|c|c|c|}
\hline No & Nama (Jenis Usaha) & $\begin{array}{c}\text { Pendapatan } \\
\text { Masyarakat } \\
\text { Sebelum } \\
\text { Mengikuti } \\
\text { Program }\end{array}$ & $\begin{array}{c}\text { Pendapatan } \\
\text { Masyarakat } \\
\text { Sesudah } \\
\text { Mengikuti } \\
\text { Program }\end{array}$ \\
\hline 1 & $\begin{array}{l}\text { Sandi Wijaya (Budidaya } \\
\text { Jamur) }\end{array}$ & Rp. 500.000 & Rp. 1.000 .000 \\
\hline 2 & $\begin{array}{l}\text { Royanah Rahmawati } \\
\text { (Kacang Jampang) }\end{array}$ & Rp. 500.000 & Rp. 1.000 .000 \\
\hline 3 & Eva Novalina (Konveksi) & Rp. 500.000 & Rp. 1.500 .000 \\
\hline 4 & Kaman (Budidaya Ikan) & Rp. 5.000 .000 & Rp. 6.000 .000 \\
\hline 5 & $\begin{array}{l}\text { Fuad Al-Anshori } \\
\text { (Sablon dan Cutting } \\
\text { Stiker) }\end{array}$ & Rp. 3.000 .000 & Rp. 7.000.000 \\
\hline 6 & Suparmiati (Jamu) & Rp.1.000.000 & Rp. 2.000 .000 \\
\hline 7 & Ika (Olahan Daun Kelor) & Rp. 1.000 .000 & Rp. 2.000 .000 \\
\hline
\end{tabular}

Sumber : Hasil Data dari Zona Madina

Berdasarkan data di atas dari 7 masyarakat yang mengikuti program pemberdayaan ekonomi masyarakat, ada perbedaan pendapatan yang mereka hasilkan sebelum dan sesudah mengikuti program. Hal ini menunjukan adanya pengaruh positif dengan adanya program pemberdayaan ekonomi masyarakat 
40 | Rifqi Hattan, Nining Nurhasanah, Firmansyah : Efektivitas Pendayagunaan Dana Zakat Terhadap Pengembangan Program Pemberdayaagunaan Ekonomi Masyarakat Pada Zona Madina Dompet Dhuafa

pada Zona Madina sehingga masyarakat dapat meningkatkan kebutuhannya untuk keperluan sehari-sehari.

\subsection{Analisis Perhitungan Efektivitas}

1. Analisis Rasio Efektivitas

Berdasarkan perhitungan yang akan dilakukan melalui rasio efektivitas, dapat diketahui bahwa tingkat efektivitas program pendayagunaan dana zakat terhadap pengembangan program pemberdayaan ekonomi masyarakat pada Zona Madina Dompet Dhuafa untuk tahun 2015-2017 adalah sebagai berikut.

Tabel 4. 2 Rasio Efektivitas

\begin{tabular}{|c|c|c|c|c|}
\hline NO & TAHUN & TARGET & REALISASI & $\begin{array}{c}\text { RASIO } \\
\text { EFEKTIVITAS }\end{array}$ \\
\hline 1 & 2015 & Rp841.933.400 & Rp. 840.033 .400 & $99,77 \%$ \\
\hline 2 & 2016 & Rp209.291.392 & Rp. 209.291 .392 & $100 \%$ \\
\hline 3 & 2017 & Rp349.900.000 & Rp. 349.900 .000 & $100 \%$ \\
\hline \multicolumn{2}{|r|}{ TOTAL } & Rp1.401.124.792 & Rp 1.398.834.400 & $\mathbf{9 9 , 9 2 \%}$ \\
\hline
\end{tabular}

Sumber data diolah, (2017)

Hasil rasio efektivitas yang telah diuraikan di atas, menunjukan bahwa tingkat efektivitas pendayagunaan dana zakat terhadap pengembangan program pemberdayaan ekonomi masyarakat pada Zona Madina Dompet Dhuafa pada tahun 2015 sebesar Rp 840.033.400 atau 99,77\% dari target yang telah ditetapkan bersama dalam sebuah anggaran sebesar Rp 841.933.400. Bila dilihat dari rasio efektivitas pendayagunaan dana zakat terhadap pengembangan program pemberdayaan ekonomi masyarakat tahun 2015 di Zona Madina Dompet Dhuafa dikategorikan sangat efektif, karena persentasenya menunjukkan $>90 \%$.

Kemudian di tahun 2016 pendayagunaan dana zakat sangat meningkat berdasarkan rasio efektivitasnya yang menunjukkan angka $100 \%$ atau $\mathrm{Rp}$ 209.291.392 dari target yang telah ditetapkan. Bila dilihat dari rasio efektivitas pendayagunaan dana zakat terhadap pengembangan program pemberdayaan ekonomi masyarakat tahun 2016 di Zona Madina Dompet Dhuafa dikategorikan sangat efektif, karena persentasenya menunjukkan $>90 \%$.

Terlihat dari tabel di atas bahwa pendayagunaan zakat mengalami peningkatan yang signifikan dari tahun 2017 atau 100\%. Kenaikan pendayagunaan ini dikategorikan sangat efektif bila dilihat dari rasio efektivitasnya, karena pendayagunaannya menunnjukkan $>90 \%$.

Jika melihat anggaran target tahun 2015, jumlah anggaran lebih besar dibandingkan dengan tahun 2016 dan 2017. Hal ini dikarenakan pada tahun 2015 awal pembentukan dan pemberian dana kepada para masyarakat penerima manfaat dana zakat disesuaikan dengan kebutuhan untuk usaha. Dan pada tahun 2016 dan 2017 anggaran target lebih sedikit dibandingkan tahun 2015 karena pada tahun itu menyesuaikan dengan kondisi para mitra usaha dan program yang akan dikembangkan Zona Madina. 
Jurnal Ekonomi dan Perbankan Syariah

Vol. 7. No.2, Agustus 2018: 27-44, ISSN (cet): 2355-1755 | ISSN (online): 25796437

| 41

Berdasarkan dari keseluruhan data di atas tahun 2016 dan 2017 mengalami peningkatan yang sangat efektif hingga 100\% jika dibandingkan tahun 2015 yang hanya mencapai 99,77. Tetapi dalam pelaksanaanya sisa dana yang ada pada tahun 2015 tetap digunakan untuk peningkatan kapasitas pemberdayaan masyarakat seperti pelatihan dan proses legalisasi UKM yang dilakukan oleh Zona Madina. Maka pendayagunaan dana zakat terhadap pengembangan program pemberdayaan ekonomi masyarakat pada Zona Madina Dompet Dhuafa sudah sangat efektif.

2. Analisis Perubahan Kondisi Ekonomi Masyarakat Penerima Bantuan Program

Perubahan kondisi ekonomi masyarakat penerima bantuan program diukur dengan indikator perubahan pendapatan karyawan antara sebelum dan sesudah intervensi dari program. Pengukuran perubahan dilakukan menggunakan Uji Statistik Wilcoxon Signed Rank Test.

Hipotesis yang akan diuji pada penelitian ini adalah :

$\mathrm{HO}=$ Program tidak berpengaruh secara signifikan terhadap kondisi ekonomi masyarakat penerima bantuan program.

$\mathrm{H} 1$ = Program berpengaruh secara signifikan terhadap kondisi ekonomi masyarakat penerima bantuan program

Berikut ini adalah hasil pengolahan data melalui bantuan program SPSS versi 17.

Tabel 4. 3 Hasil Pengolahan Data Wilcoxon Ranks

\begin{tabular}{|l|l|r|r|r|}
\hline \multicolumn{2}{|c|}{} & N & $\begin{array}{c}\text { Mean } \\
\text { Rank }\end{array}$ & $\begin{array}{c}\text { Sum of } \\
\text { Ranks }\end{array}$ \\
\hline \multirow{4}{*}{$\begin{array}{l}\text { Sebelum Program- } \\
\text { Sesudah Program }\end{array}$} & Negative Ranks & $0^{\mathrm{a}}$ & 0 & 0 \\
\cline { 2 - 5 } & Positive Ranks & $7^{\mathrm{b}}$ & 4 & 28 \\
\cline { 2 - 5 } & Ties & $0^{\mathrm{c}}$ & & \\
\cline { 2 - 6 } & Total & 7 & & \\
\hline
\end{tabular}

a. Sesudah Program < Sebelum Program

b. Sesudah Program > Sebelum Program

c. Sesudah Program $=$ Sebelum Program

\section{Dasar Pengambilan Keputusan Wilcoxon :}

Dengan membandingkan nilai wilcoxon hitung dengan wilcoxon tabel.

1. Apabila wilcoxon hitung < wilcoxon tabel, maka H0 ditolak.

2. Apabila wilcoxon hitung > wilcoxon tabel, maka H0 diterima atau H1 ditolak.

Hasil analisis terhadap uji wilcoxon dari Tabel Wilcoxon Signed Ranks.

Dari output terlihat bahwa dari 7 data kondisi ekonomi sebelum dan sesudah 
42 | Rifqi Hattan, Nining Nurhasanah, Firmansyah : Efektivitas Pendayagunaan Dana Zakat Terhadap Pengembangan Program Pemberdayaagunaan Ekonomi Masyarakat Pada Zona Madina Dompet Dhuafa

mengikuti program, tidak ada data mempunyai ranking negatif, 7 data mempunyai ranking positif dan tidak ada data dengan ranking sama. Dalam uji Wilcoxon, yang dipakai adalah jumlah ranking yang paling kecil, karena itu dalam kasus ini diambil ranking yang negatif yaitu ,00 (lihat output pada kolom 'sum of ranks'). Dari angka ini didapat hasil uji statistik Wilcoxon adalah 0.

Dengan melihat tabel Wilcoxon, untuk n (jumlah data) $=7$, uji satu sisi dan tingkat signifikasi $(\alpha)=5 \%$, maka didapat nilai wilcoxon dari tabel Wilcoxon $=5$. Dari hasil penjabaran terhadap uji wilcoxon di atas maka kesimpulan yang didapat adalah oleh karena wilcoxon hitung < wilcoxon tabel $=0<5$ maka Ho ditolak yang berarti program berpengaruh terhadap perubahan kondisi ekonomi masyarakat penerima bantuan program pemberdayaan ekonomi masyarakat.

Tabel 4. 4 Hasil Pengolahan Data Signifikasi

Test Statistics ${ }^{\mathbf{a}}$

\begin{tabular}{|l|r|}
\hline & \multicolumn{2}{|c|}{$\begin{array}{c}\text { Sesudah program - } \\
\text { Sebelum Program }\end{array}$} \\
\hline Z & $-2,414^{\mathrm{b}}$ \\
Asymp. Sig. (2-tailed) & 0,016 \\
\hline
\end{tabular}

a. Wilcoxon Signed Ranks Test

b. Based on negative ranks.

\section{Dengan Menggunakan Angka Signifkansi}

1. Jika angka signifikansi $>0,05$ maka $\mathrm{H} 0$ diterima.

2. Jika angka signifikansi < 0,05 maka H0 ditolak atau H1 diterima.

Hasil yang didapat dari tabel menunjukkan bahwa nilai Asymp. Sig. (2tailed)/asymptotic significance untuk uji dua sisi adalah 0,016. Di sini menandakan bahwa signifikansi di bawah $0,05(0,016<0,05)$ sehingga dapat disimpulkan bahwa H0 ditolak dan H1 diterima. Artinya berdasarkan uji wilcoxon dan uji signifikansi maka dapat ditarik kesimpulan bahwa program pemberdayaan ekonomi masyarakat memang mempunyai efek yang nyata/berpengaruh terhadap perubahan kondisi ekonomi masyarakat penerima bantuan program.

\section{KESIMPULAN}


Jurnal Ekonomi dan Perbankan Syariah

Vol. 7. No.2, Agustus 2018: 27-44, ISSN (cet): 2355-1755 | ISSN (online): 2579-

6437

43

Setelah melakukan penelitian, baik melalui hasil wawancara, pengamatan langsung terhadap objek penelitian dan analisis data yang ada, maka penulis dapat menyimpulkan bahwa pendayagunaan dana zakat terhadap program pemberdayaan ekonomi masyarakat pada Zona Madina Dompet Dhuafa dari tahun 2015-2017 sebesar 99,92\%. Sehingga pendayagunaan dana zakat terhadap program pemberdayaan ekonomi masyarakat pada Zona Madina Dompet Dhuafa telah berjalan sangat efektif, karena hasil rasio efektivitasnya menunjukkan $>90 \%$. Berdasarkan hasil uji statisitik nonparametrik Wilcoxon, program ini berdampak pada peningkatan kondisi ekonomi masyarakat penerima bantuan dengan signifikansi perubahan dari uji statistik menunjukkan tingkat signifikansi lebih kecil dari $\alpha$ 5\%. Sehingga program pemberdayaan ekonomi masyarakat berpengaruh positif terhadap perubahan kondisi ekonomi masyarakat penerima bantuan program. Agar social impact dari kehadiran Zona Madina ini benar-benar dirasakan oleh masyarakat, maka lebih diperhatikan lagi masyarakat yang membutuhkan yang belum menerima bantuan dana dari Zona Madina khususnya program pemberdayaan ekonomi masyarakat.

\section{DAFTAR PUSTAKA}

Arikunto, Suharsimi. (1998). Prosedur Penelitian Suatu Pendekatan Praktek. Jakarta: Rineka Cipta.

Badan Amil Zakat Nasional. (2016). Outlook Zakat Indonesia 2017. Jakarta: Pusat Kajian Strategis BAZNAS

Bisma, I Dewa Gde \& Susanto, Hery. (2010). Jurnal Ganec Swara Edisi Khusus Vol. 4 No.3. Evaluasi Kinerja Keuangan Daerah Pemerintah Propinsi Nusa Tenggara Barat Tahun Anggaran 2003-3007.

Djarwanto. (2003). Statistik Non Parametrik. Yogyakarta: BPFE.

Hafidhuddin, Didin. (2002). Zakat Dalam Perekonomian Modern. Jakarta: Gema Insani.

Hermawan, Asep. (2003). Pedoman Praktis Metodologi Penelitian Bisnis, Jakarta: LPFE Trisakti.

Jogiyanto. (2004). Metodologi Penelitian Bisnis: Salah Kaprah dan Pengalaman- Pengalaman, Yogyakarta: BPFE.

Kementerian Agama RI. (2012). Pedoman Pengawasan Lembaga Pengelola Zakat. Jakarta.

Mardiasmo. (2004). Otonomi dan Manajemen Keuangan Daerah. Yogyakarta : ANDI.

Mintarti, Nana. (2011). Bangsa Betah Miskin. Ciputat: Indonesia Magnificence of Zakat.

Mubyarto. (2000). Membangun Sistem Ekonomi. Cet 1. Yogyakarta: BPFE 
44 | Rifqi Hattan, Nining Nurhasanah, Firmansyah : Efektivitas Pendayagunaan Dana Zakat Terhadap Pengembangan Program Pemberdayaagunaan Ekonomi Masyarakat Pada Zona Madina Dompet Dhuafa

Pasolong, Harbani. (2012). Teori Administrasi Publik. Yogyakarta: Alfabeta Qardhawi, Yusuf. (2009). Kiat Islam Mengentaskan Kemiskinan, "Terj. Jakarta: Gema Insani Pers.

Rochaety, Ety dkk. (2007). Metodologi Penelitian Bisnis: Dengan Aplikasi SPSS. Jakarta: Mitra Wacana Media.

Satries, Wahyu I. (2011). Efektivitas Program Pemberdayaan Pemuda pada Organisasi Kepemudaan Al Fatih Ibadurrohman Kota Bekasi. Salemba: Pascasarjana Universitas Indonesia

Subagyo, Ahmad Wito. (2000). Efektivitas Program Penanggulangan Kemiskinan dalam Pemberdayaan Masyarakat Pedesaan. Yogyakarta : Universitas Gajah Mada.

Sumadiningrat, Gunawan. (1999). Pemberdayaan Masyarakat dan Jaringan Pengamanan Sosial. Cet 1. Jakarta: Gramedia Pustaka Utama.

Zona Madina Dompet Dhuafa. (2016). Laporan Ekografis Sebaran Desa Program Zona Madina 2016. Bogor : Zona Madina Dompet Dhuafa.

Zona Madina Dompet Dhuafa. (2016). Laporan Ekografis Sebaran Penerima Manfaat Zona Madina 2016 Bogor : Zona Madina Dompet Dhuafa.

Zona Madina Dompet Dhuafa. (2017). Company Profile Zona Madina Dompet Dhuafa.Bogor: Zona Madina Dompet Dhuafa.

Sumber Lain :

https://www.bps.go.id/index.php/linkTabelStatis/1494. Jumlah Penduduk Miskin dan Persentase Penduduk Miskin. diakses pada 10.20 WIB Selasa, 14 Agustus 2017

Situs Resmi Zona Madina https://zonamadina.com/profil/. diakses pada 08.18 WIB Senin, $15 \quad$ Januari 2018 